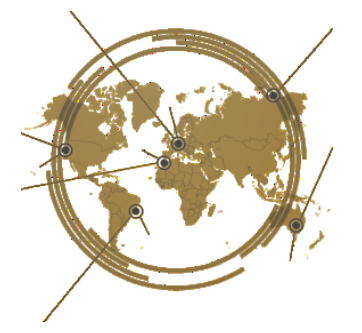

\title{
Student's strategies in online autonomous English language learning
}

\author{
Nina Inayati*, Rachyani Ayulis Rachmadhani, Berliana Nurmustika Utami
}

Universitas Muhammadiyah Malang

This study investigates the integration of online technology by English language learners, especially those done in autonomous language learning. To be more specific, this study aims to discover how systematic is students' strategies in online autonomous language learning and the supports they expect from the educational institutions and teachers/lecturers in terms of conducting effective online autonomous learning. This study mainly employs a survey design which is supported by an interview. The population of the study was the undergraduate students of English Language Education Department in a private university in Malang, East Java, Indonesia. The findings suggest that learners were less systematic in their strategy use when conducting autonomous language learning. They showed lack of long term goal setting and reported difficulty in evaluation, and mostly resort to short term planning, resource finding and execution of learning. For the reasons, avoidance of classroom-like feeling and not knowing how to evaluate was repeatedly noted. Further, they also reported high expectations of teachers and institutions' support and assistance in conducting autonomous language learning. The current study and some previous studies in the area have noted that learners tend to consider goal setting and evaluation as teachers' areas, influenced by the fixed curriculum imposed in schools and universities. As such, some flexibility in curriculum enactment and stronger intervention by teachers and institutions to support learners' autonomy are proposed.

OPEN ACCESS ISSN 25033492 (online)

${ }^{*}$ Correspondence: Nina Inayati

nina@umm.ac.id

Received: 8th September 2020 Accepted: 28th February 2021

Published: 3rd April 2021

Citation:

Inayati, Rachmadhani and Utami. (2021). Student's Strategies in Online Autonomous English Language Learning.

J. Eng. Educ. Society. 6:1. doi: 10.21070/jees.v6i1.1035
Keywords: Autonomy, Language Learning, Online Technology, Strategy

\section{INTRODUCTION}

High autonomy has been acknowledged as one of the features of successful language learners (Benson, 2013; Inayati, 2015; Wong \& Nunan, 2011). Autonomous language learning is an approach to language learning which focuses on the learners' independence to discover their learning styles and actively find and engage rich language resources outside the formal class. Inayati (2015) defines autonomy as the learners' independence to explore the techniques and learning resources that suit them the most, without formal instruction from the teachers, in order to gain maximum learning outcome. She also acknowledges that autonomy is highly effective to be applied in first-year university learners since it allows learners to arrange their learning activities to facilitate better achievement of the learning goals. 
In practice, autonomy in language learning comes in six different approaches. All of which contribute to the development of autonomy Benson (2006). First, the resource-based approach is practically used to direct learners to choose their learning method and to search the most appropriate resources for themselves. Second, the teacherbased approach aims to promote teachers' awareness towards the implementation of autonomous language learning. Here, the teachers' proficiency highly contributes to the learners' success in autonomous language learning. Third, the learnerbased approach focuses more on the development of learners' independence in the learning process. The major purpose of this approach is to assist learners in promoting their language learning quality. Fourth, the classroom-based approach gives more freedom for the learners to choose their resources as long as it is still under the primary topic. For the assessment, learners can do self-assessment by answering some exercises and deciding their homework activity. Fifth, the curriculum-based aims to adjust the curriculum by inserting autonomous language learning principles. Finally, the technology-based approach tends to focus on the utilization of technological advancement for autonomous language learning purposes. The technology-based approach is believed to greatly contribute to the development of autonomous learning due to its rapid advancement.

\section{Technology for Autonomous Language Learning}

Along with the technology advancement, autonomy in language teaching and learning sees technology as the major aspect of its application. It is proven by the research result of autonomous language learning implementation which indicates that learners are highly dependent on the technology and they were also aware that technology assists them to achieve their learning goals by providing various types of sources (Inayati, 2014, 2016). In line with this, Bravo et al (2017) agree that the enhancement of autonomous language learning goes hand in hand with technology advancement. In support of this, Benson (2006) suggests three main areas on how technology supports autonomous learning, which encompasses allowing the learners to be 'the leader' of their own learning process, providing the learners with wide resources' and access, and assisting the learners in utilizing the resources maximally in accordance with the target language. Besides, Karakas \& Kartal (2020) discusses one of the ways to engage technology with autonomous language learning by utilizing mobile applications. Specifically, they mention mobile applications often used for autonomous language learning practice: YouTube, I-tunes, TED, and Duolingo. Further, they suggest that educators and learners need to comprehend the strategies of autonomous language learning to maximize mobile applications' use to achieve the target language.

Other examples related to the use of mobile applications used for autonomous language learning were proposed by Forsythe (2013) who used Mixer, Skype, Livemocha, Second Life, among others, to promote the learners' communication skills in the English language. Those sites are used to engage foreign learners with native speakers so that they can learn from the 'actual sources'. Besides, Warschauer \& Liaw (2011) discuss other technology implementation in autonomous language learning using digital media such as blogs and Live Ink to enhance learners' reading and writing skills. Blogs give learners opportunity to improve their writing skill by allowing them to write and publish their own written texts easier. Meanwhile, the Live Ink program helps learners develop their reading skills by providing cascading text format to make the learners easier to comprehend and interpret the meaning of the text. Technology aside, the way learners utilize those technologies to assist their language learning in autonomous learning contexts are highly important to discuss.

\section{Strategies for Online Autonomous Learning}

Learning strategies is a crucial component of language learning. Language learning strategy is a series of activities that are conducted by learners to attain their learning goals (Chang \& Liu, 2013; Hardan, 2013). Zakaria et al (2017) added that language learning strategies are assorted options utilized by learners to familiarize themselves with their learning. Complementing the explanation, Nguyen \& Terry (2017) claimed that personal distinction, contexts, and environment are some of the factors which affect the choice of language learning strategy. There is no specific sequence regarding the preference of strategy use. This point was justified by Cetinave1 \& Kartal (2014) who investigated the first-years language teacher trainee in Turkish learners of a foreign language encompassing English, German, and French language teaching department, and found that the highest preference of learning strategies in their study was occupied by the use of movies and online chat, meanwhile the grammar book and test occupied the lowest preference. On the other hand, another research by Ahmadzadeh \& Zabardast (2014) who studiedthe third-year university students in Selcuk University and Hacettepe University, Turkey indicated different trend. They found that the highest learners' preference of learning strategies was by doing exercises of grammar, translation, and words, and also by grouping and comparing activities, while the lowest preference was mechanic memory. From these two different results, we can see that the preferred strategies in autonomous language learning cannot be generalized. Thus, referring to Nguyen \& Terry's (2017) statement, strategies are highly dynamic and depend on the learners' needs and the circumstances.

The strategy of autonomous language learning described in this study is largely based on Benson's (2013) idea that describes autonomy as the 'learning in which the learners themselves determine the objectives, progress, and evaluation of learning'. In practice, there are various forms of autonomy. According to Benson (2006), there are five autonomous learning strategies emerging within the language learning field. First, self-access is a strategy which provides an authentic learning facility to fulfill learners' needs to promote 
their autonomous learning. Several learning media support self-access strategy, such those encompassing audio, video and computer workstations, audiotapes, videotapes and DVDs, computer software and print materials, as well as internet or satellite. Second, distance learning is a strategy belonging to learners' who do not prefer to study in a classroom environment. The major reason for the community's high interest towards distance learning is caused by the flexibility in its application and the availability of less pressure environment. Third, tandem learning utilizes human-resources maximally by using communication as the key to this strategy. Tandem learning is learners' mutual cooperation done by conducting actual communication with other learners from different mother tongues to achieve their target language (Benson, 2013; Karjalainen et al, 2013). Karjalainen et al (2013) also adds that the formality level of tandem learning highly depends on several aspects such as age, learners' capability of autonomous learning, learning purpose, and its design. To be more detailed, the least formal version of tandem learning is the educators providing partners for the learners so they arrange their learning process; meanwhile, the most formal version is the educators being involved in each aspect of the learning process. Fourth, out of class learning strategy focused on the learners' initiation to conduct activities beyond formal education which still promote their language skill development. Out of class learning is not necessarily designed for education purposes, but learners conduct activities that contribute to enhance their language competence. Lastly, self-instruction requires a high autonomy level since its principle is that the learners need to discover their resources and ability to maintain their language learning process.

The strategies of autonomous language learning are growing rapidly due to technological advancement. This fact contributes to the further improvement of CALL (Computer Assisted Language Learning), specifically defining the autonomous language learning that maximally utilizes the technologies. Benson (2013) defines CALL as a term to indicate the use of computer software that were created or adjusted explicitly for language learning purposes. Benson also acknowledges that CALL, which in this case fall into the technology-based approach, facilitates the growth of other autonomous language learning approaches. Furthermore, Benson (2013) also mentions several extension terms which still fall under the umbrella of CALL, those terms are CMCL (Computer-Mediated Communication for Language Learning) and MALL (Mobile Language Learning). According to Mutlu \& Eröz-Tuğa (2013), Computer-Mediated Communication has two different synchronous and asynchronous types. Synchronous communication requires the participants to do direct communication (Skype and Zoom), meanwhile asynchronous communication principled that direct communication is not necessary (email, blog, message board). Mobile language learning focused on the utilization of smartphones in technology-based learning. According to Demouy et al. (2015), most learners' preferred language learning activity is listening and watching videos that can be conducted by utilizing handheld mobile devices. Moreover, they added that, despite listening and watching videos, learners can also promote their grammar, reading, and writing skills accessible in mobile devices.

Several current studies have lent support on the relative effectiveness of how technology has facilitated autonomous language learning. Hsieh \& Hsieh (2019) examine the relationship between learners' autonomous language learning behavior and the usage of Self-Access Center resources as well as the activities within it. The result shows that SAC use and autonomous language learning behavior are highly related and indicate that learners with better autonomous language learning behavior can utilize SAC maximally. Furthermore, another research by Fu \& Wang (2020) investigates the use of Wechat platform to enhance college students' autonomous learning. They claimed that there are some strategies emerging during the implementation of Wechat to promote learners' autonomous learning which are the instructional design, teaching model, inquiry and collaboration-based learners' autonomy, as well as the monitoring and feedback. Finally, Wahyuni et al. (2020) analyze the learners' impression towards the use of Edmodo to assist autonomous learning. The finding shows that learners gave positive responses towards the implementation of Edmodo for their autonomy such as convenient access and its high assistance for their English language learning.

One of the most current sub-division of CALL in English Language teaching and learning was suggested by Sockett (2014) who proposed the term Online Informal Learning of English (OILE). OILE was described as informal and autonomous learning of English occurring mostly through online entertainment-based activities that young people commonly do in their daily lives. This exposure to online forms of English, which main aims could either be for learning or pure entertainment, serves as a support in naturalistic acquisition of the language. The autonomous learning activities that Hyland (2004) and Benson (2013) had previously categorized as out-of-class language learning, when conducted online they can now be referred to as OILE activities, and those types of autonomous learning are the focus in the current study.

Considering the rich availability of literature on the topic of autonomous learning, very limited focus was given on the learners' strategies in conducting online informal learning of English, thus the focus of the current study. To be more specific, this study aims to analyze how systematic English language learners' strategies are in conducting online and informal autonomous learning, and to identify their specific expectations in terms of the supports from their educational institutions. Understanding both issues are important as they shed some lights on how language educational institutions may better facilitate the student learning by enhancing and supporting their autonomous initiative. 


\section{METHODS}

This study mainly utilizes survey design with the support of interview for data triangulation purposes. Survey was chosen as the main design due to its features which facilitate effective data gathering about certain characteristics of a given population (Ary et al, 2010; Creswell, 2012). Such design is deemed suitable with the aims of the current study, which are to investigate the strategies of students' online autonomous language learning and to examine students' expectations with regards to institutional supports for conducting autonomous learning. Cross-sectional survey was used utilizing online survey platform for practicality reasons because, as suggested by Fink (2013), such design allows data gathering to involve a big number of population spread over wide geographical areas. To crosscheck the validity of the obtained data, semi-structured interview was conducted. The interview used focus group discussion format done in small batches (two to three students) in order to obtain in-depth and saturated data in a time effective manner.

As the population, the current study involved 668 fulltime undergraduate students of an English Language Education Department in a respected private university in East Java, Indonesia. The online survey was distributed via Google Form, which link was shared to all students. The researcher initially identified and contacted all captains of each cohort in order to ask their help to share the invitation to complete the survey to their classmates. The composition of the respondents were $11 \%$ students of first year, $27 \%$ students of second year, $29 \%$ students of the third year, and $33 \%$ students of the fourth year and older. Considering the distribution, it is safe to argue that the survey result is generally representative towards the population understudied. As for the sample taken for the interview, cluster sampling technique was used as it was considered suitable for the purpose of the study. Invitation to interview was given to students of the four different academic year, and at the end of the data collection process, eight students representing the four academic years were interviewed.

The detail of the instruments used in this study were questionnaire and interview guide. The survey was developed taking into account the in-depth literature study about autonomous language learning Benson (2013) aligned with the specific aims of the study. The initial draft was made in English and sent to an expert for content and face validity purposes. However, initial piloting to two students resulted in the translation of the survey into Indonesian Language to better facilitate respondents' understanding as they came from diverse English language proficiency levels. The Indonesian version of the survey was once again validated by an ELT expert before it was-pilot tested to 20 students. Analysis of the questionnaire's internal reliability using Cronbach Alpha resulted in the coefficient of 0,812 for the learning strategy variable, and 0.785 for the expectation variable. Alluding to George \& O'Mallery's (2006) rule of thumb in reading Alpha coefficient, both are considered as good internal consistency.
The final version of the questionnaire consisted of three main sections; personal detail, general autonomous learning strategies, and expectations. The first section about personal detail asked respondents' basic demographic information such as gender, academic year and English language proficiency level. The second section about general autonomous learning strategies comprised of 5 sub-sections with a total of 9 items with five-point Likert Scale of frequency. This section generally asked student respondents about the structure of their autonomous learning from goal setting, planning, finding resources, activities and evaluation. The third section about expectation comprised of two items with six-point Likert Scale of agreement. The second research instrument used was interview guide, which was loosely based on the research questions and the results of the survey data analysis. Indonesian language was once again used as the medium of communication during the interview in order to batter facilitate the discussion and gain a more valid and in-depth insights about the answers that the students wrote in the survey and their opinions towards the general trends found in the survey data.

Once the data collected was considered sufficient, they were analyzed using descriptive statistics. Descriptive statistics was chosen as it facilitates understanding of general summary of certain population's characteristics as well as more specific trends found in a survey data (Fink, 2013). The descriptive statistics used to analyze the survey results were that of frequency and central tendency to be more detailed. For the interview data, the transcripts were analyzed using content analysis in order to find common themes and concepts mentioned by the respondents. This was done by careful and repeated listening to the interview recording and reading of the transcripts to analyze, identify (code) and categorize recurring patterns in the respondents' responses.

\section{RESULTS AND DISCUSSION}

\section{The Strategies for Autonomous Language Learning}

The exploration about the strategies that students used in conducting autonomous language learning in online settings was done by measuring how systematic their learning activities are. To do that, this study employed a survey which was developed based on an extensive review of literature. The systematic nature of students' autonomous learning was observed from five aspects; general goal setting, specific planning, learning resource finding, execution, and evaluation. Each aspect was represented by several items in the questionnaire, measured using a five-point Likert Scale of frequency ( 1 means never to 5 means always). Figure 1 illustrates the general trends found in the survey data analysis. 
FIGURE 1 | The Systematic Nuture of Students' Autonomous Learning

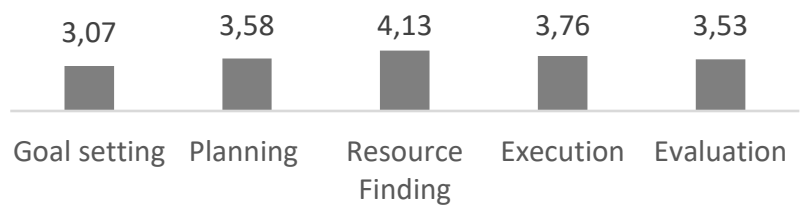

Figure 1 suggests that the two highest mean belongs to resource finding and the actual execution of the autonomous learning activities. To be more specific, for resource finding the questionnaire asked the students if they found it easy to find online resources for specific target of autonomous language learning that they wanted. The obtained mean of 4,13 means that most respondents answered 'always' and 'often', showing the relative easiness of finding and accessing autonomous learning materials online. Next, for the actual execution of the learning, the students were asked to indicate if they thought it was easy to use online resources to learn English. This item yielded a weighted mean on 3,84 (see Table 1), meaning that generally students 'often' found no problem in using and understanding them. In addition, the execution was also measured using another item asking students if they were able to focus on doing a series of activity based on the specific language aspect that they wanted to learn, which mean was 3,68 . This means that the student respondents generally reported frequent ability to do so.

Next, as can be seen in Figure 1, goal setting and evaluation has the lowest means-3,07 and 3,53 respectively, meaning that generally both items fall into the category of 'sometimes.' Goal setting represents the bigger goal in language acquisition. For this, the students were asked to indicate if they set general long-term goal(s) for their English language learning (e.g. TOEFL ITP score 500 by the end of the year), and whether they created sub-goals to achieve it (e.g. breaking it into monthly goals).Both items yielded the means of 2,97 and 3,16 respectively, which mean that many respondents answered 'seldom' and 'sometimes' for both statements. As for the evaluation, the students were asked to indicate if they assessed their own language learning in any way and whether they did any form of selfreflection to evaluate their learning gain. For both items, the means obtained were 3,49 and 3,57, meaning that quite many of them did the reflection but not so many of them did the assessment.

It is important to note that in the questionnaire, the goal setting is further broken down into specific planning, and that the planning is different from goal setting in terms of its relative closeness to the execution of the autonomous learning activities. The planning aspect yielded the grand mean of 3,58, which leans closer to 'often'. In other words, more than half of the students reported frequently making plans, albeit short term. This can be further seen in the detail of the questionnaire items, in which many students reported that they frequently made plans about the specific language aspects that they wanted to learn before findings online learning materials (mean 3,67).

The data seems to suggest that many students tend to 'just do it' when it comes to autonomous language learning. Meanwhile, long-term goal setting and evaluation seemed to be regarded as optional. When clarified during interview, the students reported several reasons for not making goals and plans first, among others are to avoid the classroom-like feeling where it was considered too rigid and demanding. As for evaluation, some reasons for why students did not do that was also to avoid being too rigid and not knowing how to.

"Plans and evaluation make it feels too rigid, like learning in classroom settings, it feels demanding. I usually just watch or listen, or just read anything, as long as it's in English, there must be some learning happening there." - I2$P R$

"Yeah, I think clear targets are important, but for me, 'just do it' feels better, haha." I3-SY

"I like watching dramas, and when I come across unfamiliar vocabulary I usually make notes and then memorize them. But for evaluation, I don't think I know how to do that." II-IS

\section{Students' Expectations for Online Autonomous Language Learning}

At the end of the survey, students were asked about the expectations that they had for the teachers/ lecturers or the educational institutions with regards to the potential support they may get. There were two items asking about this in the questionnaire, and students were to indicate if they wanted to know more about the strategies and the resources available to do online autonomous English language learning. Both items were measured using a six-point Likert Scale of agreement; 1 for totally disagree to 6 for totally agree. As seen in Table 2, the results of survey data analysis show that students expressed a very high expectation to receive assistance in both areas; the strategies and the resources to do online autonomous language learning. The means of both items are 5,30 and 5,24, which lean closer to agreement of both statements. In other words, students expected to be aided in conducting autonomous language learning, both in terms of resources and strategies to do effective learning to maximize their learning outcome.

Further exploration about this issue during interview confirmed that students were indeed showing a high interest in autonomous learning and that they expected real institutional supports. Analysis of interview data revealed that students seemed to emphasize the importance of tailoring institutional supports to the students' personal interests. As such, mapping students' interests became an important first step before designing and offering relevant supports for autonomous language learning. 
TABLE 1 | Details of Students' Autonomous Language Strategies

\begin{tabular}{|c|c|c|}
\hline Aspects & Statements & Mean \\
\hline \multirow[t]{2}{*}{$\begin{array}{l}\text { Goal } \\
\text { Setting }\end{array}$} & $\begin{array}{l}\text { I have general goals to improve my English Language proficiency (e.g. } \\
\text { TOEFL score of } 500 \text { or above) }\end{array}$ & 2,97 \\
\hline & $\begin{array}{l}\text { I divide my general goal into specific sub-goals that I can do in phases (e.g. } \\
\text { this month I will focus on learning about Past Tense.) }\end{array}$ & 3,16 \\
\hline \multirow[t]{2}{*}{ Planning } & I make due dates for each learning target, big and small, that I have. & 3,49 \\
\hline & $\begin{array}{l}\text { I make plan first about what language aspect I want to focus on before } \\
\text { finding materials online. }\end{array}$ & 3,67 \\
\hline $\begin{array}{l}\text { Resource } \\
\text { Finding }\end{array}$ & $\begin{array}{l}\text { I find it easy to find online resources for independent English language } \\
\text { learning that I want }\end{array}$ & 4,13 \\
\hline \multirow[t]{2}{*}{ Execution } & $\begin{array}{l}\text { I focus on doing a series of relevant activity until I reach my specific English } \\
\text { Language learning goal }\end{array}$ & 3,68 \\
\hline & I find it easy to learn English using online resources. & 3,84 \\
\hline \multirow[t]{2}{*}{ Evaluation } & $\begin{array}{l}\text { I assess my own English Language learning based on my specific } \\
\text { goal. }\end{array}$ & 3,49 \\
\hline & $\begin{array}{l}\text { I do self-reflection to evaluate my independent English language } \\
\text { learning }\end{array}$ & 3,57 \\
\hline
\end{tabular}

TABLE 2 | Students Expectations about Autonomous Language Learning

\begin{tabular}{lc}
\hline Statements & Mean \\
\hline I want to know more about resources available for English independent learning & 5,30 \\
\hline I want to know more about strategies to do online English independent learning & 5,24 \\
\hline
\end{tabular}

"I think there should be some kind of mapping for students' interests. For example, if students love playing games, then they can suggest some good games to support autonomous English language learning." $I 2-P R$

"Assign less structured assignments so that we can have more time for autonomous learning. It's not that we don't want to do assignments, but there should be a specific set of time for autonomous learning so that we can learn topics that are closer to our personal interests." I1-OL

This section discusses some salient findings discovered in the study and their relevance with the current literature, as well as the implications of the study for language teachers and learners. First, as indicated previously, the general basis for the systematic strategy used to measure learners' autonomous learning in online and informal settings used in this study was based on Benson (2013) suggestions. Basing his strategy on Holec's seminal works, Benson proposed five stages in conducting systematic autonomous learning, they are setting the learning goals; making specific plans; deciding the methods of learning and materials used; executing the act of learning; and evaluating the learning. For this, the findings suggest that most learners understudied showed a general tendency to 'just do it.' This is shown by the high numbers of respondents who chose to find online learning sources and use them directly, without giving much consideration to the long term goal of learning.

Besides, the data also suggests that students prefer to override some aspects of autonomous learning activities due to several reasons, such as deliberate avoidance of nonclassroom feeling. Structured learning indicated by meticulous goal planning and evaluation was categorized as too serious and belong to classroom learning, while informal out of class learning was supposed to be, as Lai \& Gu (2011) suggested, less demanding, and personally relevant and encouraging. Sockett (2014) acknowledges that informal learning focuses on the utilization of resources which are not designed for educational purposes. In other words, the use of popular resources such as songs, online videos, movies or social media posts, could assist language learners in autonomous language learning. This is true even though they do not necessarily focus on the linguistic aspects when enjoying those resources, a phenomenon that Sockett refers to as online informal learning of English (OILE).

Previous studies have also suggested that goal setting and evaluation were two aspects that many learners considered to be the teachers' responsibilities, albeit in autonomous learning contexts (Khotimah et al, 2019 and in SchebBuenner, 2019). In her study, Khotimah et al (2019) investigated the classroom-based independent learning activities of the third year secondary school students in East Java province, Indonesia, encompassing 10 schools. They found that the learners showed lower initiatives in doing the initiating (goal setting and planning) and evaluating aspects compared to the monitoring and execution aspects.In another setting involving an international college in Thailand

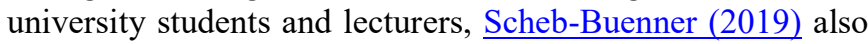
found that identical results; low planning and evaluation by learners due to general perceptions that both aspects were lecturers' areas. This phenomenon may be the result of years 
of institutionalized learning, where in school and university, students mostly learn based on the teachers' meticulous arrangement. In other words, following the curriculum, teachers set the goal and plans of learning activities for the students, and do the evaluation after the learning activities was deemed sufficient. As a result, learners seem to show difficulty in breaking out of the institutionalized learning patterns, even in autonomous learning contexts as early adults. This aspect was also acknowledged by Genç (2015) who investigated the influence of personal factors towards the autonomous learning capacity of students and teachers in foreign language majors. He found that patent curriculum design has somehow 'crippled' students' opportunity and ability to modify and rearrange it. It is worth noting that effective autonomous learning demands reflection as part of evaluation. As Reinders (2010) suggests, reflection is a crucial aspect of autonomous learning as it assists learners to be aware of their lacks and mistakes to improve their future performance.

Another finding of the current study worth highlighting is the learners' high expectations concerning the support and assistance from teachers and institutions in the implementation of autonomous language learning. The expected supports involve the strategies and access to available resources for English language learning. Indeed, as Jafari et al (2017) found in their study investigating the advance and intermediate EFL learners' perceptions and practices of autonomous learning, learners at both levels tend to hand over the strategy arrangement to the teachers. Furthermore, Lai (2015) also noted that teachers' instruction and references regarding the learning resources influence learners' autonomous learning ability as it reinforces their positive perceptions, enhancing the ability to access, and modelling the effective utilization of technology for autonomous language learning.

The current study and the previous relevant studies have consistently shown that learners' autonomy in language learning are mostly lacking in longer term goal setting and evaluation, and mostly limited of short term planning, resource finding and execution. The lack of structure in learners' autonomous learning may be influenced by years of learning in school as well as university in which the fixed curriculum has left the students mostly as followers especially in long term planning and evaluation aspects. As such, teachers and language institutions could consider offering a more flexible curriculum which leave some space for negotiating the specific goals that they want to attain and how they want to be evaluated. In this case, teachers' intervention is also essential and expected. As stated by $\underline{\mathrm{Xu}}$ (2015), although learners were the 'key-holder' of their learning, teachers' role is also crucial in promoting learner's autonomy. For example, learners could be given some options of specific language learning goals, and together with the teachers, they can design and arrange some learning activities - thus training them about autonomous learning strategies - and its evaluation. Such instructional design would train learners' autonomy by sensitizing them with the systematic and effective stages in conducting autonomous learning, as well as in how to conduct and evaluate the progress.

\section{CONCLUSION}

This study has found that the autonomous learning strategy that learners use in online informal autonomous language learning was less systematic in that they lack in long term goal setting. The students tend to cut the process and jump to short term planning, learning resource locating and accessing, and learning execution. Further, they also reported low frequency in evaluation. The findings suggest that many learners did not set learning goals, and some did not even do any planning at the beginning as they tend to avoid classroom-like feeling when doing informal online language learning autonomously. As for the evaluation, learners showed low awareness of its importance in learning, especially in informal, out of class settings, and lack of ideas on how to evaluate their learning. In addition to the strategy, learners expressed high interests in conducting autonomous language learning, and expected that teachers and institutions provide supports in terms of strategy and access to relevant resources. Albeit done autonomously in out-of-class contexts, the findings of the current study reflect the classroom behavior where learners mostly depend to the teachers on the goal setting and evaluation, and did autonomous learning based on a short term interests. Therefore, a more flexible curriculum which allows some space of negotiation is offered to train students to conduct systematic and effective autonomous learning activities to support their language learning.

This study may be limited in terms of the number of respondents and geographical reach, but the insights gained could give an initial overview of how systematic English language learners are in their informal language learning in online settings. Further studies could focus on broadening the population and focusing on how to improve flexibility in curriculum development and implementation to better cater autonomy in formal language instructions.

\section{ACKNOWLEDGMENT}

This research was supported by the research grant from the Directorate of Research and Community Service of the University of Muhammadiyah Malang. 


\section{REFERENCES}

Ahmadzadeh, R., \& Zabardast, S. (2014). Learning Autonomy In Practice. International Journal on New Trends in Education and Their Implications , 5(4), 49-57.

Ary, D., Jacobs, L, C., Sorensen, C., \& Razavieh, A. (2010). Introduction to Research in Education (8th ed.). Wardswoth Cengage Learning. Canada: Nelson Education Ltd Exotic Classic.

Benson, P. (2006). Autonomy in language teaching and learning. Language Teaching, 40(1), 21-40. https://doi.org/10.1017/S0261444806003958

Benson, P. (2013). Teaching and researching: Autonomy in language learning. Routledge

Bravo, J. C., Intriago, E. A., Holguin, J. V., Garzon, G. M., \& Arcia, L. O. (2017). Motivation and Autonomy in Learning English as Foreign Language: A Case Study of Ecuadorian College Students. English Language Teaching, 10(2), 100. https://doi.org/10.5539/elt.v10n2p100

Çetinavcı, U. R., \& Kartal, E. (2014). Autonomous language learning strategies of Turkish foreign language teacher trainees in view of receptive and productive skills development. Language, 55-68.

Chang, C. H., \& Liu, H. J. (2013). Language learning strategy use and language learning motivation of Taiwanese EFL university students. Electronic Journal of Foreign Language Teaching, 10(2), 196209.

Creswell, J. W. (2012). Educational Research: Planning, Conducting, and Evaluating Quantitative and Qualitative Research (4th, revised ed.). Pearson Education.

Demouy, V., Jones, A., Kan, Q., Kulkuska-Hulme, A., \& Eardley, A. (2015). Why and how do distance learners use mobile devices for language learning? The EUROCALL Review, 23(2), 10-24.

Forsythe, E. (2013). Autonomous language learning with technology. The JALT CALL Journal, 9(3), 329337.

Fink, A. (2013). How to conduct surveys. Sage Publications.

Fu, \& Wang. (2020). Developing College Students ' English Autonomous Learning through WeChat Public Platform. 942-952. https://doi.org/10.4236/ce.2020.116068

Genç, G. (2015). International Journal of Languages' Education and Teaching AUTONOMOUS LEARNING CAPACITY OF EFL STUDENT TEACHERS 1 Gülten GENÇ International Journal of Languages' Education and Teaching. International Journal of Languages' Education and Teaching, 3(2), 23-42.

George, D., \& Mallery, P. (2006). SPSS for Windows step by step: a simple guide and reference. Allyn and Bacon.
Hardan, A. A. (2013). Language Learning Strategies: A General Overview. Procedia - Social and Behavioral Sciences, 106, 1712-1726. https://doi.org/10.1016/j.sbspro.2013.12.194

Hsieh, H. C., \& Hsieh, H. L. (2019). Undergraduates' out-ofclass learning: Exploring EFL students' autonomous learning behaviors and their usage of resources. Education Sciences, 9(3), 12-17. https://doi.org/10.3390/educsci9030159

Hyland, F. (2004). Learning autonomously: Contextualising out-of-class english language learning. Language Awareness, 13(3), 180-202. https://doi.org/10.1080/09658410408667094

Inayati, N. (2014). English Language Teachers ' Attitude Towards Social Media in Higher Education : Indonesian Perspective. 777-790.

Inayati, N. (2015). Promoting English Independent Study for EFL University Students in Indonesia. Language Education in Asia, 6(1), 46-57. https://doi.org/10.5746/leia/15/v6/i1/a5/inayati

Inayati, N. (2016). Integrating English Independent Study in Pronunciation Course. In PROCEEDINGS The 63rd TEFLIN International Conference 2016 Creativity and Innovation in Language Materials Development and Language Teaching Methodology in Asia and Beyond

Jafari, S., Ketabi, S., \& Tavakoli, M. (2017). Advanced and intermediate EFL learners' perceptions and practices of autonomous learning. ITL - International Journal of Applied Linguistics, 168(1), 70-90. https://doi.org/10.1075/itl.168.1.03jaf

Karakaş, A., \& KArtal, G. (2020). Pre-Service Language Teachers' Autonomous Language Learning with Web 2.0 Tools and Mobile Applications. International Journal of Curriculum and Instruction 12(1), 12(1), 51-79.

Karjalainen, K., Pörn, M., Rusk, F., \& Björkskog, L. (2013). Classroom tandem - Outlining a model for language learning and instruction. International Electronic Journal of Elementary Education, 6(1), 165-184.

Khotimah, K., Widiati, U., Mustofa, M., \& Faruq Ubaidillah, M. (2019). Autonomous English learning: Teachers' and students' perceptions. Indonesian Journal of Applied Linguistics, 9(2), 371-381.

https://doi.org/10.17509/ijal.v9i2.20234

Lai, C. (2015). Modeling teachers' influence on learners' self-directed use of technology for language learning outside the classroom. Computers and Education, 82, 74-83. https://doi.org/10.1016/j.compedu.2014.11.005

Lai, C., \& Gu, M. (2011). Self-regulated out-of-class language learning with technology. Computer Assisted Language Learning, 24(4), 317-335. https://doi.org/10.1080/09588221.2011.568417

Mutlu, A., \& Eröz-Tuğa, B. (2013). The role of ComputerAssisted Language Learning (CALL) in promoting learner autonomy. In Egitim Arastirmalari - Eurasian Journal of Educational Research (Issue 51, pp. 107122). 
Nguyen, H., \& Terry, D. R. (2017). English Learning Strategies among EFL Learners: A Narrative Approach. IAFOR Journal of Language Learning, 3(1), 4-19. https://doi.org/10.22492/ijll.3.1.01

Reinders, H. (2010). Towards a classroom pedagogy for learner autonomy: A framework of independent language learning skills. Australian Journal of Teacher Education, 35(5), 40-55. https://doi.org/10.14221/ajte.2010v35n5.4

Scheb-Buenner, P. (2019). University Students' Perception on Autonomous Learning: A Case of Private University, Thailand. In ICES 2018: The 1st International Conference on English Studies Organizing Committee (p. 321).

Selwyn, N. (2009). The digital native - myth and reality. Aslib Proceedings: New Information Perspectives, 61(4), 364-379. https://doi.org/10.1108/00012530910973776

Sockett, G. (2014). The Online Informal Learning of English. In The Online Informal Learning of English. Palgrave Macmillan UK. https://doi.org/10.1057/9781137414885

Wahyuni, S., Mujiyanto, J., Rukmini, D., Fitriati, S. W., \& Handoyo, B. (2020). Integrating edmodo into english instruction: Students' perceptions and its contribution to autonomous learning. International Journal of Scientific and Technology Research, 9(2), 15901595. https://doi.org/10.13140/RG.2.2.21102.56649

Warschauer, M., \& Liaw, M. (2011). Emerging technologies for autonomous language learning. Studies in SelfAccess Learning Journal, 2(3), 107-118.

Wong, L. L. C., \& Nunan, D. (2011). The learning styles and strategies of effective language learners. System, 39(2), 144-163. https://doi.org/10.1016/j.system.2011.05.004

$\mathrm{Xu}$, L. (2015). A Study on College English Teachers' Role in Developing Learner Autonomy. Theory and Practice in Language Studies, 5(2), 435. https://doi.org/10.17507/tpls.0502.27

Zakaria, N. L., Aziz, A. A., \& Ramayah, K. (2017). Language learning strategies and learner autonomy in learning Japanese. Journal of Advanced Research in Social and Behavioural Sciences, 9(3), 50-60.
Conflict of Interest Statement: The authors declare that the research was conducted in the absence of any commercial or financial relationships that could be construed as a potential conflict of interest.

Copyright (C) 2021 Inayati, Rachmadhani and Utami. This is an open-access article distributed under the terms of the Creative Commons Attribution License (CC BY). The use, distribution or reproduction in other forums is permitted, provided the original author(s) and the copyright owner(s) are credited and that the original publication in this journal is cited, in accordance with accepted academic prac- tice. No use, distribution or reproduction is permitted which does not comply with these terms. 